\title{
Chemical soil and leaf properties in yellow passion fruit cultivation with organic fertilization
}

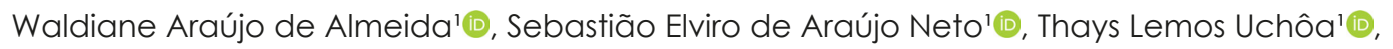

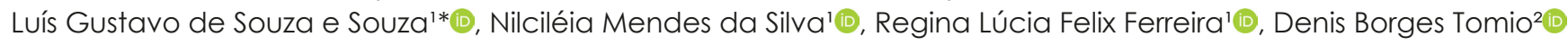

'Federal University of Acre, Rio Branco, Acre, Brazil

${ }^{2}$ Federal Institute of Acre, Tarauacá, Acre, Brazil

"Corresponding author, e-mail: gustavo_souza_fj@hotmail.com

\begin{abstract}
The yellow passion fruit presents a high nutritional demand, and successive cultivations in the same area lead the soil to nutritional exhaustion, creating the need for restitution through fertilizers. In the context of organic managements, alternatives must be sought, which, besides improving soil fertility, can increase the contents of soil organic matter. Therefore, this work aimed to evaluate the effect of organic basal fertilization in passion fruit cultivation on the chemical properties of the soil and nutrient contents of the plant. Two experiments were performed in two rural properties, with soils presenting sandy-loam and clay-loam texture. The experimental design was in randomized blocks (RBD), with 5 treatments and 4 blocks. The treatments consisted of the application of organic compost in different planting hole diameters: $0.4 \mathrm{~m} ; 0.8 \mathrm{~m} ; 1.2 \mathrm{~m} ; 1.6 \mathrm{~m}$, and $2.0 \mathrm{~m}$, and their respective volumes of organic compost: $0.0007 \mathrm{~m}^{3} ; 0.03 \mathrm{~m}^{3} ; 0.06 \mathrm{~m}^{3}, 0.10 \mathrm{~m}^{3} ; 0.16 \mathrm{~m}^{3}$. The chemical characteristics of the soil and the foliar content of nutrients were evaluated. Soil texture interferes with the effects of organic fertilization. Regardless of the texture, fertilization increases the contents of organic matter and $\mathrm{P}$ in the soil. The successive organic cultivation in a sandy-loam soil increases the content of $\mathrm{P}$ and provides higher foliar contents of N, P, Ca, Mg, S, B, Cu, Fe, Zn, and Na.
\end{abstract}

Keywords: organic fertilization, soil management, Passiflora edulis S., soil texture

\section{Introduction}

Passiflora edulis Sims (yellow passion fruit) is the passion fruit species of highest economic importance in Brazil, given its productivity, juice yield, acidity content, flavor, and aroma, which makes it the most preferred by consumers (Santos et al., 2017; Meletti, 2011). According to IBGE (2018), the national production in 2018 was $602.651 \mathrm{t}$, with a yield of $14.1 \mathrm{tha}^{-1}$. The crop occupies a prominent place in national fruit farming, although it presents a high nutrient demand, especially in tropical soils, to which the inclusion of technologies contributes to higher yields (Meletti, 2011 ; Uchôa et al., 2018).

The intensive soil use with agricultural crops removes a large part of nutrients, which are used for plant growth and development and then exported by harvests, generating the need for nutritional restitution in the agroecosystem. Therefore, it is important to verify the nutritional demand of the crop, which may vary for the passion fruit with the developmental stage of the plant, yield goal, and amount of nutrients present in the soil in order to perform a rational application of fertilizers (Mattar et al., 2018).

Nutrient stock analysis and application should be efficiently calculated, especially for fast-growing and short or medium-cycle crops, such as the passion fruit, which, according to Rodrigues et al. (2017), is responsive to nutrient availability in the soil.

The soil is one of the main resources in agriculture, and the factors related to its quality are determining in plant development, requiring agricultural practices that regenerate fertility with the increment or the contents of soil organic matter, which contribute to the improvement of physical, chemical, and biological properties, and indirectly to plant development (Melo et al., 2017; Vezzani \& Mielniczuk, 2011). For that purpose, soil management must comprise the fallow period, implantation, and 
senescence of the crop, keeping the soil covered with vegetation (Araújo Neto et al., 2014b).

The conditions of soil constant covering with a diversity of plants, in the context of organic cultivation, constitute practices that increase soil microbial activity as a consequence of the high plant biomass produced with organic fertilization and the absence of agrochemicals (Araújo Neto et al., 2014a).

The fruit cultivation system can modify soil nutrient contents. The application of organic matter increases its levels in up to $14 \%$ in banana cultivation but can reduce in the cultivation of species of Citrus (Guimarães et al., 2014). In the organic plum cultivation, Chocano et al. (2016) observed the increase of organic matter and microbial activity when using organic compost, with a high positive correlation between yield and organic carbon, total N, total $\mathrm{P}$, and available K.

Soil organic matter is an important nutrient stock source for agricultural crops. Furthermore, it assists in the infiltration of water and air, promotes water retention, contributes to soil aggregation, and complexes agrochemical molecules (Guimarães et al., 2014). With that, it contributes to the viability of agricultural activities, rural development, and environmental conservation (Melo et al., 2017).

Thus, this work aimed to evaluate the effect of organic basal fertilization in yellow passion fruit cultivation on the chemical properties of the soil and nutrient contents of the plant.

\section{Material and Methods}

The experiment was performed in two rural properties: the Seridó Ecological Site (Property 1), located on Porto Acre Road, km 04, José Rui Lino Branch, km 1.7, in Rio Branco, AC, 0953' 16" S latitude and 67\%49' 11 "' W longitude, with an elevation of $170 \mathrm{~m}$, and São Raimundo Farm (Property 2), located on Highway AC 10, km 22. Flaviano Melo Branch, Line 10, km 7, in Porto Acre, 09०48' 18" S latitude and 67039' 11 " W longitude.

The climate in both places is classified as hot and humid, Am-type, according to Köppen, with a mean annual temperature of $24.5^{\circ} \mathrm{C}$, air relative humidity of $84 \%$, and annual rainfall varying from $1,700 \mathrm{~mm}$ to 2,400 $\mathrm{mm}$, according to the INMET data.

The soil of Property 1 is classified as an Alitic Plinthic YELLOW ARGISOL with sandy-loam texture, without apparent erosion and with moderate drainage. The nutrient contents in the $0-20 \mathrm{~cm}$ depth layer were: $\mathrm{pH}$ $\left(\mathrm{H}_{2} \mathrm{O}\right)=5.1 ; \mathrm{P}=2.0 \mathrm{mg} \mathrm{dm}^{-3} ; \mathrm{K}=1.8 \mathrm{mmol}_{\mathrm{c}} \mathrm{dm}^{-3} ; \mathrm{Ca}=19$ $\mathrm{mmol}_{\mathrm{c}} \mathrm{dm}^{-3} ; \mathrm{Mg}=9 \mathrm{mmol}_{\mathrm{c}} \mathrm{dm}^{-3} ; \mathrm{Al}=8$, and $\mathrm{H}=64 \mathrm{mmol}_{\mathrm{c}}$ $\mathrm{dm}^{-3}$; organic matter $=17 \mathrm{~g} \mathrm{dm}^{-3}$; base saturation $=29.8 \%$. The area had been previously used for the cultivation of vegetables, lying fallow in the previous two years and followed by passion fruit cultivation.

The soil in Property 2 is classified as a Plinthic Dystrophic RED ARGISOL with silty clay loam texture. The nutrient contents in the $0-20 \mathrm{~cm}$ depth layer were: $\mathrm{pH}$ $\left(\mathrm{H}_{2} \mathrm{O}\right)=5.2 ; \mathrm{P}=2.0 \mathrm{mg} \mathrm{dm}^{-3} ; \mathrm{K}=1.2 \mathrm{mmol}_{\mathrm{c}} \mathrm{dm}^{-3} ; \mathrm{Ca}=27$ $\mathrm{mmol}_{\mathrm{c}} \mathrm{dm}^{-3} ; \mathrm{Mg}=11 \mathrm{mmol}_{\mathrm{c}} \mathrm{dm}^{-3} ; \mathrm{Al}=18 ; \mathrm{H}=70 \mathrm{mmol}_{\mathrm{c}}$ $\mathrm{dm}^{-3}$; organic matter $=27 \mathrm{~g} \mathrm{dm}^{-3}$; base saturation $=39.2 \%$. The area was used for 20 years for pasture cultivation without herbicides or chemical fertilization, and in the last two years it also lied fallow, followed by passion fruit cultivation.

The experimental design was in randomized blocks (RBD) with 5 treatments, 4 blocks, and four plants per plot, totaling 20 experimental plots. The treatments were constituted by cylindrical planting holes with 0.15 $\mathrm{m}$ of depth, with the application of organic compost in different planting hole diameters: $0.4 \mathrm{~m} ; 0.8 \mathrm{~m} ; 1.2 \mathrm{~m} ; 1.6$ $\mathrm{m}$, and $2.0 \mathrm{~m}$, and their respective volumes of organic compost: $0.0007 \mathrm{~m}^{3} ; 0.03 \mathrm{~m}^{3} ; 0.06 \mathrm{~m}^{3}, 0.10 \mathrm{~m}^{3}$; and 0.16 $\mathrm{m}^{3}$, respectively. To avoid the effect of soil preparation, all treatments had planting holes with $2.0 \mathrm{~m}$ of diameter. To neutralize the difference of nutrients ( $K$ and $P$ ) between treatments with differentiated values of organic compost, thermophosphate and potassium sulfate were applied to balance the contents in the treatments.

The yellow passion fruit seedlings were produced in July 2014, in plastic bags containing $1.57 \mathrm{~L}$ of substrate produced in the property, based on soil, organic compost, ground ouricuri palm stem, and ground charcoal, in the ratio of $3: 3: 3: 1$, adding $1 \mathrm{~kg} \mathrm{~m}^{-3}$ of dolomitic limestone and $1.5 \mathrm{~kg} \mathrm{~m}^{-3}$ of natural thermophosphate. A sample of the substrate was sent to ICASA (Instituto Campineiro de Análise de Solo e Adubo) for analysis, presenting the following nutrient contents: $\mathrm{pH}\left(\mathrm{H}_{2} \mathrm{O}\right)=6.5 ; \mathrm{P}=20.2 \mathrm{mg} \mathrm{L}^{-1}$; $\mathrm{K}=348 \mathrm{mg} \mathrm{L}^{-1} ; \mathrm{Ca}=153 \mathrm{mg} \mathrm{L}^{-1} ; \mathrm{Mg}=88 \mathrm{mg} \mathrm{L}^{-1} ; \mathrm{S}=87.1 \mathrm{mg}$ $\mathrm{L}^{-1} ; \mathrm{B}=0 ., 28 \mathrm{mg} \mathrm{L}^{-1} ; \mathrm{Cu}=0.03 \mathrm{mg} \mathrm{L}^{-1} ; \mathrm{Fe}=1.99 \mathrm{mg} \mathrm{L}^{-1} ; \mathrm{Mn}=$ $0.82 \mathrm{mg} \mathrm{L}^{-1} ; \mathrm{Na}=12 \mathrm{mg} \mathrm{L}^{-1}$.

The cultivar used was an F2 synthetic variety of the public domain constituted by genotypes $2,20,22,23$, 33,35 , and 37 , from the passion fruit germplasm bank of UFAC. The seedlings remained in a plant nursery covered with a $100 \mu$ transparent film and laterals closed with a shading cloth, receiving daily irrigation.

For the preparation of the area, a backpack brush cutter was used to remove the spontaneous vegetation. All planting holes were manually opened, adding $1 / 3$ of the soil volume in the planting hole with the 
organic compost (treatments).

Transplantation occurred in November 2014, conducted in a vertical shoot positioning system with 2 meters height and 1 string of smooth wire $n^{\circ} 12$ in a 3.0 $x 3.0 \mathrm{~m}$ spacing. The agricultural practices employed in the ecological cultivation of passion fruit were those described by Rezende et al. (2017), Uchôa et al. (2018), and Silva et al. (2019), observing the Normative Instruction $n^{\circ}$. 46, of October 6, 2011.

The organic compost used was produced based on sawdust, coffee straw, dry grass, rice husk, poultry litter, and bovine manure, obtained from a company specialized in the production of organic fertilizers. The organic compost sample was sent to ICASA, and the results of the chemical characteristics are presented in Table 1.

Table 1. Chemical analysis of the organic compost used for fertilization in the planting holes.

\begin{tabular}{|c|c|c|c|c|c|c|c|c|c|c|c|c|c|c|}
\hline & CEC & CIN & M.O. & $\mathrm{N}$ & $\mathrm{Ca}$ & $\mathrm{Mg}$ & $S$ & $P$ & $K$ & $\mathrm{Fe}$ & $\mathrm{Mn}$ & Zn & $\mathrm{Cu}$ & $B$ \\
\hline PH & CEC & $C / N$ & & & $-\%-$ & ----- & & $\% \mathrm{P}_{2} \mathrm{O}_{5}$ & $\% \mathrm{~K}_{2} \mathrm{O}$ & & & $n g \mathrm{~kg}^{-1}$ & & \\
\hline 6.28 & 21.8 & 18.39 & 86.07 & 0.65 & 1.76 & 0.11 & 0.24 & 2.8 & 0.21 & $20,696.2$ & 345.53 & 76.02 & 19.18 & 82.63 \\
\hline
\end{tabular}

To analyze the soil characteristics, soil samples were collected in both experiments two years after their implantation, in the distance of $0.5 ; 1.0$, and $1.5 \mathrm{~m}$ from the base of the plant, collecting three sub-samples to compose the total sample, at a depth from 0 to $10 \mathrm{~cm}$, with the aid of a probe. The analyzed variables were the chemical characteristics of the soil: $\mathrm{pH}$, contents of $\mathrm{P}$, $\mathrm{K}^{+}, \mathrm{Ca}^{2+}, \mathrm{Mg}^{2+}, \mathrm{Al}^{3+}, \mathrm{H}+\mathrm{Al}, \mathrm{M} . \mathrm{O}$., besides the CEC in $\mathrm{pH}$ 7 and the sum of bases (SB), according to the analytical procedures presented by Claessen et al. (1997).

For the foliar analysis, 20 mature leaves without petiole and containing one flower bud at the side were collected per plot and sent to the laboratory, following the methodology proposed by Carvalho et al. (2011). The content of primary macronutrients $(N, P, K)$, secondary macronutrients ( $\mathrm{Ca}, \mathrm{Mg}, \mathrm{S})$, and micronutrients $(\mathrm{B}, \mathrm{CU}, \mathrm{Fe}$, $\mathrm{Mn}, \mathrm{Zn}, \mathrm{Na}, \mathrm{Al}, \mathrm{Co}, \mathrm{Mo}, \mathrm{Cl}$ ) was verified.

Soil and leaf collections were performed between
May and June 2016.

The data were subjected to the verification of assumptions of the analysis of variance. Afterwards, the analysis of variance was performed by the $\mathrm{F}$ test, followed by the joint analysis of the experiments (the properties). Regression analyses were performed for the quantitative factors, and Tukey's test was used for the qualitative factors at a $5 \%$ level of probability.

\section{Results and Discussion}

The soil sampling at $0.5 \mathrm{~m}$ from the base of the plant presented the best values for all variables, including those in which there was a need to unfold the factors.

In both soils, at $0.5 \mathrm{~m}$ from the base of the plant, it was possible to observe a higher content of nutrients (Table 2). However, except for K, in the clayey soil, the remaining values did not differ from each other in greater distances.

Table 2. Contents of potassium (K), magnesium (Mg), cation exchange capacity (CEC) and base saturation (V\%) in sandy-loam and clay-loam soils sampled at $0.5 ; 1.0$, and $1.5 \mathrm{~m}$ from the base of the yellow passion fruit plants, in Rio Branco - AC, 2016.

\begin{tabular}{|c|c|c|c|c|c|c|c|c|}
\hline \multirow{3}{*}{$\begin{array}{l}\text { Distance from } \\
\text { the plant (m) }\end{array}$} & \multicolumn{4}{|c|}{ Clay loam } & \multicolumn{4}{|c|}{ Sandy loam } \\
\hline & K & $M g$ & CEC & & K & $\mathrm{Mg}$ & CEC & \\
\hline & \multicolumn{4}{|c|}{---mmol $\mathrm{dm}^{-3}$} & \multicolumn{3}{|c|}{-----'mmol $\mathrm{dm}_{\mathrm{c}}^{-3}$} & $v(\%)$ \\
\hline 0.5 & $5.9 \mathrm{a}$ & $20.6 a$ & $113.4 \mathrm{a}$ & $73.9 a$ & $3.2 \mathrm{a}$ & $14.1 \mathrm{a}$ & $81.5 a$ & $75.4 a$ \\
\hline 1.0 & $4.1 \mathrm{ab}$ & $15.9 \mathrm{~b}$ & $96.1 \mathrm{~b}$ & $57.5 \mathrm{~b}$ & $2.4 \mathrm{~b}$ & $13.9 a$ & $66.4 a$ & $95.0 \mathrm{a}$ \\
\hline 1.5 & $2.6 \mathrm{~b}$ & $15.3 \mathrm{~b}$ & $90.9 \mathrm{~b}$ & $55.9 \mathrm{~b}$ & $2.3 \mathrm{~b}$ & $12.5 a$ & $60.5 a$ & $63.9 \mathrm{a}$ \\
\hline CV (\%) & 81.7 & 20.2 & 9.9 & 10.1 & 34.6 & 16.5 & 12.2 & 87.0 \\
\hline
\end{tabular}

For more mobile nutrients, such as potassium (Malavolta, 2006), no difference is noted between the sampling of 1.0 and $1.5 \mathrm{~m}$, regardless of the size of the fertilized area (Table 1). Moraes et al. (2011) affirm that there may be a difference of the $K$ contents in the soil after different doses until 145 days after transplantation; from 174 days onwards, the plant requires and absorbs a lot of potassium for flowering and fructification.

The contents of phosphorus were increased with the increase in the fertilized area, in both soil textures, in the distance of $0.5 \mathrm{~m}$ from the base of the plant (Figure 1). At 1.0 from the base of the plant, the mean of the $P$ content was $10.1 \mathrm{mg} \mathrm{dm}^{-3}$ in the sandy soil and $4.9 \mathrm{mg} \mathrm{dm}^{-3}$ in the clayey soil, whereas, at $1.5 \mathrm{~m}$, the content was 6.2 $\mathrm{g} \mathrm{dm}^{-3}$ and $3.4 \mathrm{~g} \mathrm{dm}^{-3}$, respectively. This difference in the content of $\mathrm{P}$ between clayey soils of different textures may be related to the contents of clay and their mineralogical components in the fraction (Brasil \& Nascimento, 2010). 


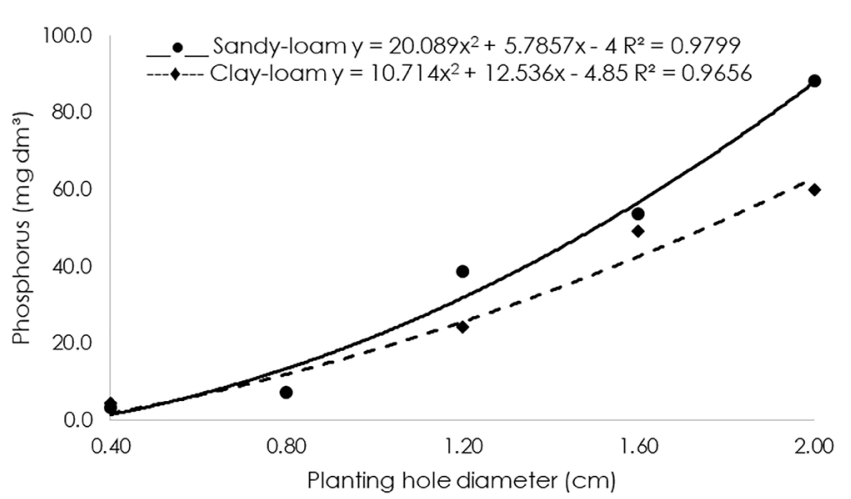

Figure 1. Content of phosphorus in the sandy-loam and clayloam soils with the application of organic compost in different planting hole diameters for yellow passion fruit, at $0.5 \mathrm{~m}$ from the base of the plant, in Rio Branco/Acre, 2016.

The increase in the distance from the base of the plant conditioned a reduction in the content of phosphorus in the soil, confirming that this is a low-mobility nutrient (Silva \& Delatorre, 2009) and constituting and indicative to concentrate fertilization in the region of the highest concentration of the root system, which, for the passion fruit plant, $80 \%$ of the roots are found at up to 1.3 $\mathrm{m}$ of distance from the base of the plant (Freitas et al., 2009).

The content of potassium decreased with the increase in the area fertilized with organic compost, in the sandy-loam soil. In the clay-loam soil, there was no adjustment $(p>0.05)$ in the regression analysis, with a mean value of the $K$ content equal to $4.2 \mathrm{mmol}_{\mathrm{C}} \mathrm{dm}^{3}$, higher than all treatments in the sandy soil, regardless of the sampling distance (Figure 2).

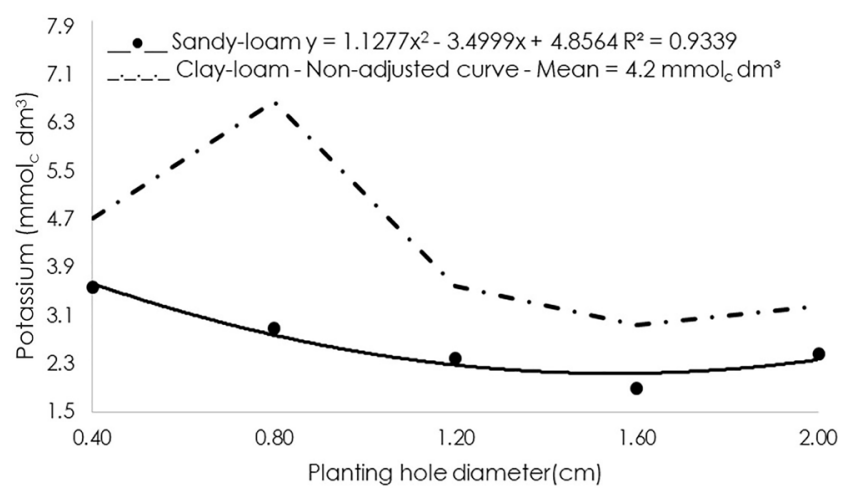

Figure 2. Potassium content of sandy-loam and clay-loam soils with the application of organic compost in different planting hole diameters for yellow passion fruit, in Rio Branco/Acre, 2016.

Likewise, in the planting holes with smaller fertilized area with organic compost, soluble fertilize were added up to the diameter of $2.0 \mathrm{~m}$ to match the amount of nutrient added in the remaining treatments. These fertilizers exhibit a faster release and may have influenced the result.
It is worth noting that, according to the IAC (2018), potassium contents above $2 \mathrm{mmol} \mathrm{dm}^{-3}$ are considered average, and according to the classification, none of the treatments stood below this level, leaving satisfactory amounts available for the plants, in all treatments.

According to Pacheco et al. (2017), to compensate the low yield of yellow passion fruits $19.0+$ $\mathrm{ha}^{-1}$ ) it is necessary to apply the double of the potassium dose via organic fertilizer (bovine manure) compared to the chemical fertilizer, resulting in higher production and number of fruits.

The content of organic matter responded by quadratic function for both soils, being significant only at a $0.5 \mathrm{~m}$ distance from the base of the plant. However, the contents were considered high, especially for the regions with weathered soils, with a hot and moist climate. However, organic fertilization allied to successive organic cultivation causes the content of organic matter to be increased above $3.5 \%$, reaching up to $7.5 \%$ in the sandyloam and clay-loam soils (Figure 3 ).

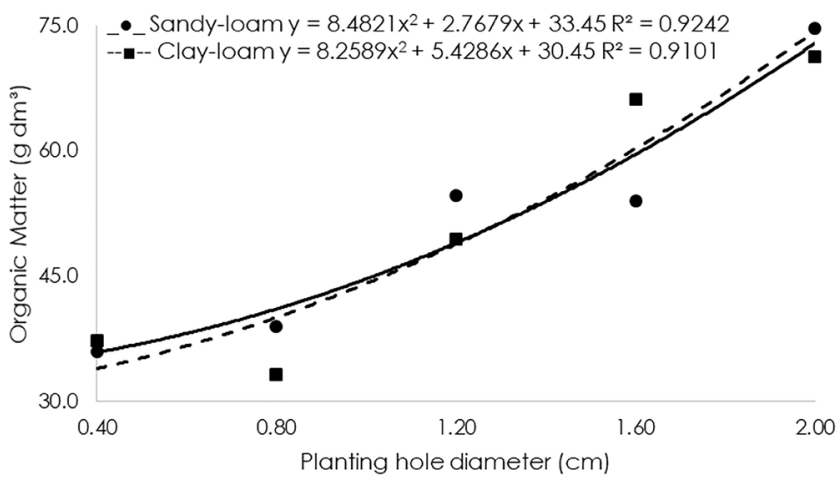

Figure 3. Content of organic matter and sandy-loam and clayloam soils with the application of organic compost in different planting hole diameters for yellow passion fruit, at $0.5 \mathrm{~m}$ from the base of the plant, in Rio Branco/Acre, 2016.

The clay-loam soil presents the advantage of possessing a higher clay content and, therefore, it is more likely to present a higher base saturation ( $\mathrm{V} \%$ ) and cation exchange capacity (CEC) since clays are the main responsible for these indices in the mineral fraction of the soil. In the sandy-loam soil, cultivated with vegetables and organic fruits and receiving a greater biomass input, the organic fraction of the soil is more stabilized, whereas, in the soil with clay-loam texture, the 20 years of pasture and cassava cultivation received less biomass input. Thus, the supply of organic matter, in the form of organic compost, acts in the improvement of the chemical and physical characteristics of soils (Mantovani et al., 2017).

In spite of the use of the organic matter content as an index for the indirect determination of nitrogen and to increase the CEC in soils with poorly-reactive 1:1 clays (Malavolta, 2006; IAC, 2018), it is worth noting that there 
are different fractions of organic matter, and soil stability results from the coexistence of these different fractions.

Something that differs between soils under cultivation with yellow passion fruit, in the two properties with ecological agriculture, is the time of cultivation and soil texture.

Through the soil sampling at the distances of 1.0

(A)

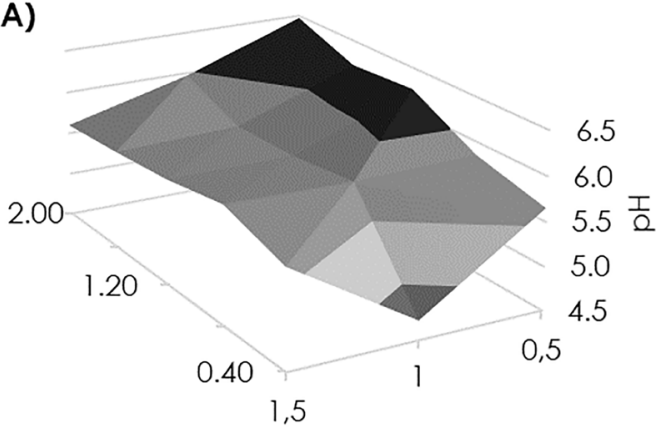

and $1.5 \mathrm{~m}$ from the base of the plant, it was possible to observe a lower potential of hydrogen (pH), and at $0.5 \mathrm{~m}$ the $\mathrm{pH}$ was higher as the fertilized area increased, with a consequent increase in the amount of organic compost added to the planting hole. This trend occurred in both cultivated soils (Figure $4 \mathrm{~A}$ and $\mathrm{B}$ ).

(B)

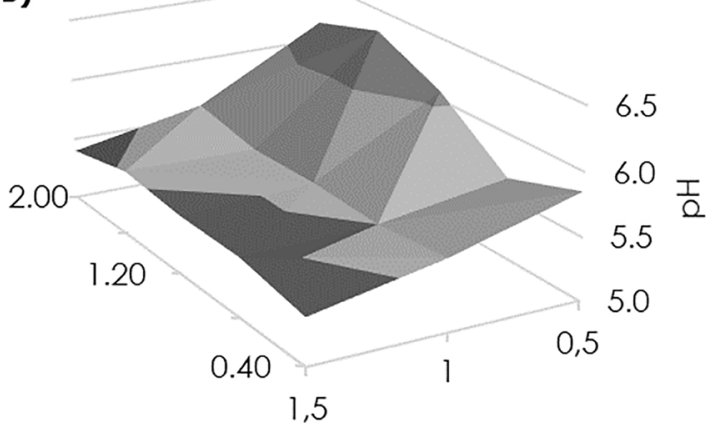

Figure 4. Response surface for the $\mathrm{pH}$ in water in sandy-loam (A) and clay-loam soil (B) with the application of organic compost in different planting hole diameters for yellow passion fruit, in Rio Branco/Acre, 2016.

The $\mathrm{pH}$ is a fundamental indicator of soil chemical conditions, presenting the ability to interfere with the availability of several chemical elements that are essential to plant development. Soil texture affects the stability and formation of aggregates, and soils with higher clay contents favor aggregation (Vezzani \& Mielniczuk, 2011). Sandy horizons hinder the formation of aggregates (Santos et al., 2011). The organic matter is more efficient in $\mathrm{pH}$ alteration in soils that contain small amounts of clay.

Soil acidity caused by the organic matter is originated by $\mathrm{COOH}$ and phenolic groupings; however, humic substances overcome acidity due to their soil buffer capacity, reacting with organic compounds containing nitrogen atoms in tetrahedral coordination (quaternary nitrogen) and presenting a positive charge (Baldotto \&
Baldotto, 2014).

The recommended soil $\mathrm{pH}$ range is from 5.5 to 6.5 , allowing the availability of a greater nutrient amount, and according to Natale et al. (2012), acidification occurs with higher intensity in the canopy projection by the application of organic residues.

Foliar sampling is a complementary tool in soil analysis. For the macro and micronutrients of the plants cultivated in both soils, there was no difference between the foliar contents found as a consequence of the increase in the size of the planting holes.

The yellow passion fruit cultivated in the sandy-loam soil presented statistically superior means of foliar contents compared to the clay-loam soil, except for potassium and manganese, whose means were similar in both soils (Table 3).

Table 3. Concentrations of nitrogen (N), phosphorus (P), potassium (K), calcium (Ca), magnesium (Mg), sulfur $(\mathrm{S})$, boron (B), copper (CU), iron (Fe), manganese ( $\mathrm{Mn})$, zinc ( $\mathrm{Zn})$, and sodium ( $\mathrm{Na}$ ) in leaves of yellow passion fruit cultivated in sandy-loam and clay-loam soils, in Rio Branco/AC, 2016.

\begin{tabular}{|c|c|c|c|c|c|c|c|c|c|c|c|c|}
\hline Soil Texture & $N$ & & $P$ & & K & & $\mathrm{Ca}$ & & $\mathrm{Mg}$ & & $S$ & \\
\hline Sandy-loam & 41.37 & $a$ & 2.65 & $a$ & 36.85 & $a$ & 11.42 & $a$ & 2.58 & $a$ & 4.16 & $A$ \\
\hline Clay-loam & 34.16 & $b$ & 2.30 & $b$ & 38.48 & $a$ & 9.21 & $b$ & 1.97 & $b$ & 3.51 & B \\
\hline CV (\%) & 12.62 & & 12.43 & & 8.07 & & 17.87 & & 18.45 & & 13.78 & \\
\hline Soil Texture & B & & $\mathrm{Cu}$ & & $\mathrm{Fe}$ & ng $k$ & $\mathrm{Mn}$ & & Zn & & $\mathrm{Na}$ & \\
\hline Sandy-loam & 11.5 & $a$ & 5.53 & $a$ & 64.01 & $a$ & 130.87 & $a$ & 60.36 & $a$ & 588.77 & $a$ \\
\hline Clay-loam & 9.67 & $b$ & 4.77 & $b$ & 54.54 & $\mathrm{~b}$ & 141.45 & $a$ & 49.95 & $b$ & 312.81 & $\mathrm{~b}$ \\
\hline $\mathrm{CV}(\%)$ & 13.72 & & 15.16 & & 7.09 & & 22.54 & & 15.56 & & 42.44 & \\
\hline
\end{tabular}

The foliar contents of $\mathrm{P}, \mathrm{K}, \mathrm{Mg}, \mathrm{S}, \mathrm{Mn}$, and $\mathrm{Z}$ of the yellow passion fruit cultivated in the sandy-loam soil were within the range considered adequate by Oliveira (2002).
It is worth noting that, regardless of being or not within the adequate range, no nutrient deficiency symptoms were identified in any of the cultivations. The nutritional contents 
of the leaves presented significant variations with the developmental stage of the plants. The accumulation of nutrients in the plants of yellow passion fruit, in $\mathrm{g} \mathrm{plant}^{-1}$, at 450 days after planting (DAS), was as follows: $N(178.5)>$ $\mathrm{K}(162.4)>\mathrm{Ca}(70.8)>\mathrm{Mg}(14.8)>\mathrm{S}(13.3)>\mathrm{P}(11.0)$, and in $\mathrm{mg} \mathrm{plant}^{-1}$ : Fe (827.6) > Mn (130.7) > Zn (69.8) > B (56.7) $>\mathrm{Cu}$ (17.8), with the highest demand for macronutrients occurring from 314 to 450 DAS, and micronutrients from 304 to 450 DAS (Mattar et al., 2018).

The increment of potassium fertilization in the soil provided evenness in the contents of $K$ in the passion fruit foliar tissues, for both soils. The potassium contents considered adequate in the leaves of the adult passion fruit plants were within 20-30 $\mathrm{g} \mathrm{kg}^{-1}$, according to Oliveira (2002).

The $\mathrm{K}$ contents are above the recommended values. Mattar et al. (2018), when evaluating the accumulation and exportation of nutrients by the yellow passion fruit CV. IAC 275 verified similar results, although the results found by Silva Júnior et al. (2013), when evaluating the nutritional status and foliar chlorophyll in the yellow passion fruit as a function of biofertilizers, liming, and fertilization with $\mathrm{N}$ and $\mathrm{K}$, verified lower values. The amount of organic fertilizer and potassium applied to the soil was sufficient to make potassium available at adequate levels for the crop.

The total accumulation of manganese in the dry matter of passion fruit plants was the same for different types of soil. The contents of $\mathrm{Mn}$ are within the adequate range (40 to $250 \mathrm{mg} \mathrm{kg}^{-1}$ ) to plant nutrition (Oliveira, 2002). This element is essential since it participates in the synthesis of chlorophyll, activation of enzymes, and in the photosystem II, which is responsible for the photolysis of water (Taiz \& Zeiger, 2013). This micronutrient is subject to great variation, without presenting any deficiency symptoms.

\section{Conclusions}

Soil texture interferes with the effects of organic fertilization. Regardless of soil texture, fertilization increases the contents of organic matter and $\mathrm{P}$ in the soil.

The successive organic cultivation in the soil with sandy-loam texture increases the content of $P$ and provides higher foliar contents of $\mathrm{N}, \mathrm{P}, \mathrm{Ca}, \mathrm{Mg}, \mathrm{S}, \mathrm{B}, \mathrm{Cu}$, $\mathrm{Fe}, \mathrm{Zn}$, and Na.

The yellow passion fruit cultivated in sandy-loam soil presents higher nutrient contents compared to those cultivated in clay-loam soil, regardless of the added volume of organic compost. It also develops plants with higher foliar contents of N, P, Ca, Mg, S, B, Cu, Fe, Zn, and $\mathrm{Na}$ than in soils with clay-loam texture.

\section{Acknowledgments}

The present work was performed with the support of the Coordination for the Improvement of Higher Education Personnel - Brazil (CAPES) - Financing Code 001, and the National Council for Scientific and Technological Development (CNPq).

\section{References}

Araújo Neto, S.E., Silva, A.N., Kusdra, J.F., Kolln, F.T., Andrade Neto, R.C. 2014b. Atividade biológica de solo sob cultivo múltiplo de maracujá, abacaxi, milho, mandioca e plantas de cobertura. Revista Ciência Agronômica 45: 650-658.

Araújo Neto, S.E., Campos, P.A., Tavella, L.B., Solino, A.J.S., Silva, I.F. 2014a. Organic polyculture of passion fruit, pineapple, corn and cassava: the influence of green manure and distance between espaliers. Ciência e Agrotecnologia 38: 247-255.

Baldotto, M.A., Baldotto, L.E.B. 2014. Ácidos húmicos. Revista Ceres 61: 856-881.

Brasil, E.C., Nascimento, E.V.S. 2010. Influência de calcário e fósforo no desenvolvimento e produção de variedades de maracujazeiro-amarelo. Revista Brasileira de Fruticultura 32: 892-902.

Carvalho, A.J.C., Fontes, P.S.F., Freitas, M.S.M., Monnerat, P.H., Fontes, A.G. 2011. Yellow passion fruit plant nutritional diagnosis at different phenological stages by the diagnosis and recommendation integrated system method. Journal of Plant Nutrition 34: 61 4-626.

Chocano, C., Garcia, C., Gonzáles, D., Aguilar, J. M., Hernández, T. 2016. Organic plum cultivation in the Mediterranean region: The médium-term effect of five different organic soil management practices on crop production and microbiological soil quality. Agriculture, Ecosystems and Enviroment 221: 60-70.

Claessen, M.E.C., Barreto, W.O., Paula, J.L., Duarte, M.N. 1997. Manual de métodos e análises de solo. 2.ed. EMBRAPA-CNPS, Rio de Janeiro, Brazil. 212 p.

Freitas, C.A.S., Costa, C.A.G., Bezerra, F.M.L., Montenegro, A.A.T., Teixeira, A.S. 2009. Sistema radicular de maracujazeiro irrigado submetido a diferentes níveis de potássio. Scientia Agraria 10: 175-183.

Guimarães, D.V., Gonzaga, M.I.S., Melo Neto, M.J.O. 2014. Management of soil organic matter and carbon storage in tropical fruit crops. Revista Brasileira de Engenharia Agrícola e Ambiental 18: 301-306.

IAC. Instituto Agronômico de Campinas. Centro de pesquisa e desenvolvimento de solos erecursos ambientais. 2018. Informação sobre interpretação de análise do solo.http://www.iac.sp.gov.br/produtoseservicos/ analisedosolo/interpretacaoanalise.php/<Access on 15 Nov. 2018>.

IBGE. Instituto Brasileiro de Geografia e Estatística. Produção agrícola municipal: culturas temporárias e permanentes. 2018. https://sidra.ibge.gov.br/ 
tabela/1613\# resultado/ <Access on 26 Apr. 2020>.

Malavolta, E. 2006. Manual de nutrição mineral de plantas. Agronômica Ceres, São Paulo, Brazil. 638 p.

Mantovani, J.R., Carrera, M., Moreira, J.L.A., Marques, D.J., Silva, A.B. 2018. Fertility properties and leafy vegetable production in soils fertilized with cattle manure. Revista Caatinga 30: 825-836.

Mattar, G.S., Moraes, C.C., Meletti, L.M.M., Purqueiro, L.F.V. 2018. Accumulation and exportation of nutrients by yellow Passion fruit cV. IAC 275. Revista Brasileira de Fruticultura 33: e-178.

Meletti, L.M.M. 2011. Avanços na cultura do maracujá no Brasil. Revista Brasileira de Fruticultura 33: 83-91.

Melo, V.F., Silva, D.T., Evald, A., Rocha, P.R.R. 2017. Qualidade química e biológica do solo em diferentes sistemas de uso em ambiente de savana. Revista Agro@ mbiente On-line 11: 101-110.

Moraes, J.C.B., Salcedo, I.H., Sousa, V.F. 2011. Doses de potássio por gotejamento no estado nutricional do maracujazeiro. Revista Brasileira de Engenharia Agrícola e Ambiental 15: 763-770.

Natale, W., Rozane, D.E., Parent, L.E., Parent, S.E. 2012. Acidez do solo e calagem em pomares de frutíferas tropicais. Revista Brasileira de Fruticultura 34: 1294-1306.

Oliveira, S.A. 2002. Análise foliar. In: Sousa, D.M.G., Lobato, E. (Ed.). Cerrado: correção do solo e adubação. Embrapa Cerrados, Planaltina, DF, Brazil. p. 245-256.

Pacheco, A.L.V., Pagliarini, M.F., Freitas, G.B., Santos, R.H.S. Serrão, J.E., Zanuncio, J. C. 2017. Mineral composition of pulp and production of the yellow passion fruit with organic and conventional fertilizers. Food Chemistry 217: 425-430.

Rezende, M.I.F.L., Araújo Neto, S.E., Lustosa, C., Hafle, O.M., Pinto, G.P. 2017. Grafting for the recovery of yellow passion fruit stem in organic system. Revista Brasileira de Fruticultura 39: e-745.

Rodrigues, D.L., Viana, A.P., Vieira, H.D., Santos, E.A., Silva, F.H.L., Santos, C.L. 2017. Contribution of production and seed variables to the genetic divergence in passion fruit under different nutrient availabilities. Pesquisa Agropecuária Brasileira 52: 607-614.

Santos, D.C., Pillon, C.N., Flores, C.A., Lima, C.L.R., Cardoso, E.M.C., Pereira, B.F., Mangrich, A.S. 2011. Agregação e frações físicas da matéria orgânica de um Argissolo Vermelho sob sistemas de uso no bioma Pampa. Revista Brasileira de Ciência do Solo 35: 1735-1744.

Santos, V.A., Ramos, J.D., Laredo, R.R., Silva, F.O.R., Chagas, E.A., Pasqual, M. 2017. Produção e qualidade de frutos de maracujazeiro-amarelo provenientes do cultivo com mudas em diferentes idades. Revista de Ciências Agroveterinárias 16: 33-40.

Silva Júnior, G.B., Cavalcante, I.H.L., Albano, F.G., Osajima, J.A. 2013. Estado nutricional e clorofila foliar do maracujazeiro-amarelo em função de biofertilizantes, calagem e adubação com N e K. Revista de Ciências Agrárias 36: 163-173.

Silva, A.A., Delatorre, C.A. 2009. Alterações na arquitetura da raiz à disponibilidade de fósforo e nitrogênio. Revista de Ciências Agroveterinárias 8: 152-163.

Silva, N.M., Araújo Neto, S.E., Souza, L.G.S., Uchôa, T.L., Ferreira, R.L.F. 2019. Organic cultivation of yellow passion fruit using tall seedlings with long root systems. Comunicata Scientiae 10: 477-483.

Taiz, L., Zeiger, E. 2013. Fisiologia vegetal. 5.ed. Artmed Editora, Porto Alegre, Brazil. 918 p.

Uchôa, T.L., Araújo Neto, S.E., Selhorst, P.O., Rodrigues, M.J.S., Galvão, R.O. 2018. Yellow Passion fruit performance in organic crop under mulch. Revista Brasileira de Fruticultura 40: e-2012.

Vezzani, F.M., Mielniczuk, J. 2011. Agregação e estoque de carbono em Argissolo submetido a diferentes práticas de manejo agrícola. Revista Brasileira de Ciência do Solo 35: 213-223.

Conflict of Interest Statement: The authors declare that the research was conducted in the absence of any commercial or financial relationships that could be construed as a potential conflict of interest.

All the contents of this journal, except where otherwise noted, is licensed under a Creative Commons Attribution License attribuition-type BY. 